\title{
Penerapan Model Pembelajaran Kooperatif Tipe Time Token Arends Dengan Media Pop Up Untuk Meningkatkan Keterampilan Berbicara Pada Siswa Kelas lii Sd Negeri 3 Kalirejo Tahun Ajaran 2017/2018
}

\author{
Shanty Wijayanti ${ }^{1}$, Suhartono ${ }^{2}$, Imam Suyanto ${ }^{3}$ \\ 1,2,3 Universitas Sebelas Maret \\ wijayantishantyy@gmail.com
}

\section{Article History}

accepted 01/02/2019

approved 01/03/2019

published 01/04/2019

\begin{abstract}
The objectives of this research are to describe steps on the application of Time Token Arends cooperative learning model using Pop Up media and to improve speaking skills through the application of Time Token Arends cooperative learning model using Pop Up media in third-grade students of SD Negeri 3 Kalirejo in the academic year of 2017/2018. This research was conducted in three cycles. Each cycle consisted of two meetings including planning, action, observation, and reflection. The subjects of the research were third grade students of SD Negeri 3 Kalirejo with totaling 26 students. The conclusion of this research is the application of Time Token Arends cooperative learning model using Pop Up media can improve speaking skills for the third-grade students of SD Negeri 3 Kalirejo in the academic year of 2017/2018.
\end{abstract}

Keywords: time token arends, pop up, speaking skills

\section{Abstrak}

Tujuan penelitian ini adalah mendeskripsikan langkah-langkah penggunaan model pembelajaran kooperatif tipe Time Token Arends dengan media Pop Up dan meningkatkan keterampilan berbicara melalui penerapan model pembelajaran kooperatif tipe Time Token Arends dengan media Pop Up pada siswa kelas III SD Negeri 3 Kalirejo tahun ajaran 2017/2018. Penelitian ini dilaksanakan dalam tiga siklus. Masing-masing siklus terdapat dua pertemuan yang terdiri dari tahap perencanaan, pelaksanaan, pengamatan, dan refleksi. Subjek penelitian adalah siswa kelas III SD Negeri 3 Kalirejo dengan jumlah 26 siswa. Simpulan dari penelitian ini adalah penerapan model pembelajaran kooperatif tipe Time Token Arends dengan media Pop Up dapat meningkatakan keterampilan berbicara pada siswa kelas III SD Negeri 3 Kalirejo tahun ajaran 2017/2018.

Kata Kunci: time token arends, pop up, keterampilan berbicara 


\section{PENDAHULUAN}

Keterampilan berbahasa merupakan keterampilan penting untuk melakukan interaksi komunikasi dalam masyarakat. Ada beberapa urutan dalam memperoleh keterampilan berbahasa, diawali dengan belajar menyimak bahasa, kemudian berbicara, setelah itu belajar membaca dan menulis. Keterampilan menyimak dan berbicara tanpa disadari telah dipelajari sebelum memasuki sekolah. Ketemapilanketerampilan tersebut pada dasarnya merupakan catur tungal dan merupakan suatu kesatuan (Tarigan, 2015: 1).

Salah satu komponen yang penting dalam keterampilan berbahasa yaitu keterampilan berbicara karena sering digunakan dalam kehidupan sehari-hari sebagai media komunikasi lisan untuk berinteraksi dengan manusia. Sesuai dengan kodrat manusia yaitu sebagai makhluk sosial. Dalam berkomunikasi dengan sesama manusia hal utama yang paling dibutuhkan adalah berbicara, Tarigan (2015: 16) berpendapat, "Berbicara adalah kemampuan mengucapkan bunyi-bunyi artikulasi atau kata-kata untuk mengekspresikan, menyatakan serta menyampaikan pikiran, gagasan dan perasaan." Dalam berbicara hendaknya kita menguasai apa yang hendak kita katakan sehingga tidak terjadi kesalah pahaman. Sebab tujuan utama dalam berbicara adalah untuk menyampaikan pikiran secara efektif dengan memahami makna mengenai segala sesuatu yang ingin dikomunikasikan (Tarigan, 2015: 16).

Keefektifan berbicara merupakan bagian penting yang menentukan keberhasilan kita dalam semua bidang kehidupan. Nurjamal, Sumirat dan Darwis (2015: 4) memberikan batasan apabila seseorang tersebut sudah terampil dalam memilih bunyi-bunyi bahasa baik itu kata, kalimat, tekanan dan nada untuk menyampaikan gagasan, pikiran, perasaan secara lisan kepada orang lain, mitra bicara atau pendengar dengan benar, akurat dan lengkap sehingga orang lain paham maksud yang disampaikan maka bisa dikatakan orang tersebut sudah terampil dalam berbicara.

Pembelajaran keterampilan berbicara merupakan inti dari kegiatan pembelajaran berbahasa, maka hal ini harus menjadi perhatian penting di sekolah dasar karena keterampilan berbicara yang rendah dapat mempengaruhi jalannya proses belajar mengajar sehingga memberi dampak juga terhadap prestasi siswa.

Keadaan nyata keterampilan siswa kelas III SD Negeri 3 Kalirejo masih tergolong sangat rendah. Rendahnya keterampilan berbicara diketahui dari hasil observasi pembelajaran dan wawancara dengan guru kelas III SD Negeri 3 Kalirejo. Berdasarkan hasil observasi tanggal 2 November 2017 di kelas III SD Negeri 3 Kalirejo Kecamatan Kebumen Kabupaten Kebumen saat pembelajaran bercerita diperoleh data pengamatan yaitu: (1) siswa cukup aktif untuk maju kedepan kelas namun belum terarah; (2) siswa malu-malu sehingga belum nampak ekspresif saat bercerita; (3) siswa belum mendapatkan kesempatan yang sama untuk bercerita; (4) siswa kesulitan menemukan ide dalam bercerita; (5) siswa saat bercerita belum runtut.

Bertolak dari hasil wawancara tanggal 2 November 2017 dengan guru kelas III SD Negeri 3 Kalirejo Kecamatan Kebumen Kabupaten Kebumen saat pembelajaran bercerita diperoleh data yaitu: (1) guru sulit mengarahkan siswa untuk berbicara runtut, karena siswa kurang dilatih untuk berbicara terutama di depan kelas sehingga pembicaraan yang siswa sampaikan masih terbata-bata. (2) guru menilai bahwa keterampilan berbicara siswa kelas III SD Negeri 3 Kalirejo masih sangat rendah karena belum mencapai standard. (3) guru merasa siswa masih kesulitan saat berbicara karena masih ada yang mengalami kesulitan dalam membaca dan menulis sehingga berpengaruh pada keterampilan berbicara siswa; (4) guru merasa siswa kurang aktif dan termotivasi saat bercerita karena guru menyadari belum menggunakan media dan model yang menarik. 
Berdasarkan kenyataan di atas, maka ketidakberhasilan bukan hanya terletak dari siswa akan tetapi juga berasal dari guru. Seorang guru juga harus mampu menerapkan model dan media pembelajaran yang tepat, karena dalam proses pembelajaran membutuhkan model dan media pembelajaran yang sesuai dengan kebutuhan siswa agar pembelajaran menjadi kondusif dan tujuan pembelajaran akan tercapai. Keberhasilan penggunaan model dan media pembelajaran bergantung pada tujuan pembelajaran dan kemampuan guru dalam mengelola proses pembelajaran.

Penelitian ini mengguakan model pembelajaran kooperatif tipe Time Token Arends sebagai model pembelajaran keterampilan berbicara. Adapun alasan pemilihan model pembelajaran ini dirasa lebih tepat karena langkah dalam model pembelajaran kooperatif tipe Time Token Arends dapat membuat siswa terangsang untuk aktif berbicara di depan kelas. Huda (2013: 239-240) berpendapat "Model ini digunakan untuk melatih dan mengembangkan keterampilan sosial agar siswa tidak mendominasi pembicaraan atau diam sama sekali. Guru memberi sejumlah kupon berbicara dengan waktu \pm 30 detik per kupon pada tiap siswa. sebelum berbicara siswa menyerahkan kupon terlebih dahulu pada guru." Hal ini tentu akan membuat siswa termotivasi untuk berlatih berbicara di depan kelas karena sudah terlatih dan terbiasa berbicara.

Sejalan dengan pendapat Shoimin (2014: 216) yang menyataan bahwa "Model pembelajaran ini mengajak siswa aktif sehingga tepat digunakan dalam pembelajaran berbicara di mana pembelajaran ini benar-benar mengajak siswa untuk aktif dan belajar berbicara di depan umum, mengungkapkan pendapatnya tanpa harus merasa takut dan malu." Dengan demikian berdasarkan beberapa pendapat diatas, model pembelajaran kooperatif tipe Time Token Arends merupakan model pembelajaran yang mengajak siswa aktif untuk berani berbicara dideapan umum dengan memberikan kupon bicara guna memberikan kesempatan bicara kepada setiap siswa yang hendak maju untuk mengungkapkan pikirannya.

Bertolak dari masalah siswa kelas III di SD Negeri 3 Kalirejo yang masih kurang runtut dan kurang menguasai topik bahasan saat bercerita, maka peneliti juga menggunakan media Pop Up dalam pembelajaran yang nantinya akan mempermudah siswa dalam bercerita. Mengingat kelebihan Pop Up yaitu dapat merangsang siswa untuk bercerita lewat rangsangan visual yang didalamnya memuat topik atau tema sehingga dapat dijadikan sumber bahan cerita siswa.

Media Pop Up mengandung unsur-unsur seperti tokoh, waktu, tempat, suasana, alur dan sudut pandang yang mendukung siswa untuk membuat peta konsep dan draft cerita, kemudian siswa mampu mengembangakan lagi menjadi sebuah cerita yang dilisankan. Cerita siswa juga semakin sesuai dengan tema pada Pop Up dan jalan ceritanya semakin runtut (Astuti, 2015: 119).

Berdasarkan dari uraian di atas maka peneliti berupaya meningkatkan keterampilan berbicara melalui penelitian tindakan kelas secara kolaboratif dengan menerapan model pembelajaran kooperatif tipe Time Token Arends dengan media Pop Up untuk meningkatkan keterampilan berbicara pada siswa kelas III SD Negeri 3 Kalirejo tahun ajaran 2017/2018. Rumusan masalah dari penelitian ini yaitu: (1) bagaimana langkah-langkah penggunaan model pembelajaran kooperatif tipe Time Token Arends dengan media Pop Up untuk meningkatkan keterampilan berbicara pada siswa kelas III SD Negeri 3 Kalirejo tahun ajaran 2017/2018?; (2) apakah penerapan model pembelajaran kooperatif tipe Time Token Arends dengan media Pop Up dapat meningkatkan keterampilan berbicara pada siswa kelas III SD Negeri 3 Kalirejo tahun ajaran 2017/2018?.

Berdasarkan rumusan masalah, maka tujuan peneltian ini yaitu: (1) untuk mendeskripsikan langkah-langkah penggunaan model pembelajaran kooperatif tipe Time Token Arends dengan media Pop Up untuk meningkatkan keterampilan berbicara 
pada siswa kelas III SD Negeri 3 Kalirejo tahun ajaran 2017/2018; (2) Untuk meningkatkan keterampilan berbicara siswa melalui model pembelajaran kooperatif tipe Time Token Arends dengan media Pop Up pada siswa kelas III SD Negeri 3 Kalirejo tahun ajaran 2017/2018.

\section{METODE}

Penelitian ini merupakan Penelitian Tindakan Kelas (PTK) kolaboratif. Penelitian ini dilaksanakan di SD Negeri 3 Kalirejo, Kecamatan Kebumen, Kabupaten Kebumen pada tahun ajaran 2017/2018. Subjek penelitian dalam penelitian ini adalah siswa kelas III SD Negeri 3 yang berjumlah 26 siswa.

Teknik pengumpulan data dalam penelitian ini meliputi teknik tes, observasi dan wawancara. Tes dalam penelitian ini digunakan untuk mengetahui peningkatan keterampilan berbicara siswa. Observasi dan wawancara dalam penelitian ini dilakukan untuk memperoleh data berdasarkan proses pembelajaran Bahasa Indonesia dengan menerapkan model pembelajaran kooperatif tipe Time Token Arends dengan media Pop Up.

Teknik yang digunakan untuk mengecek validitas data dalam penelitian ini adalah triangulasi. Triangulasi dalam pengujian kredibilitas adalah pengecekan data dari berbagai sumber melalui berbagai cara dan waktu (Sugiyono, 2016: 273).

Penelitian ini dilaksanakan dalam tiga siklus. Setiap siklus terdiri dari dua pertemuan. Prosedur penelitian yang digunakan untuk memperoleh data yang sesuai dengan permasalahan dan tujuan penelitian, peneliti menggunakan prosedur penelitian yang digunakan oleh Arikunto (2013: 137) setiap siklus terdiri dari empat tahap yaitu perencanaan (planning), pelaksanaan (acting), pengamatan (observing), dan refleksi (reflecting). Pada perencanaan peneliti menyusun RPP dan perangkat pembelajaran lainnya, melakukan koordinasi dengan guru kelas dan menghubungi observer. Pada pelaksanaan guru melaksanakan pembelajaran sesuai dengan perencanaan yang telah dibut. Pada pengamatan, observer mengamati langkah-langkah penggunaan penggunaan model pembelajaran kooperatif tipe Time Token Arends dengan media Pop Up terhadap guru dan siswa. Pada tahap refleksi dilakuakn oleh peneliti, guru kelas, dan observer untuk mendiskusikan kendala yang dijumpai selama pelaksanaan serta mencarai solusi supaya kendala tersebut dapat diatasi.

\section{HASIL DAN PEMBAHASAN}

Pelaksanaan tindakan ini dilaksanakan selama 3 siklus. Setiap siklus terdapat 2 pertemuan. Penelitian ini menggunakan langkah-langkah model pembelajaran kooperatif tipe Time Token Arends dengan media Pop Up sebagai berikut: (1) penyampaian tujuan pembelajaran menggunakan media Pop Up, (2) pembagian kelompok yang beranggotakan 4-5 siswa, (3) pemberian tugas sesuai tema Pop Up, (4) pembagian kupon bicara, (5) berbicara setelah menyerahkan kupon, (6) penilain berbicara.

Data hasil observasi terhadap guru dan siswa selama pembelajaran berlangsung dengan menerapkan model pembelajaran kooperatif tipe Time Token Arends dengan media Pop Up sebagai berikut:

Tabel 1. Hasil Observasi terhadap Guru dan Siswa

\begin{tabular}{cccc}
\hline No & Siklus & \multicolumn{2}{c}{ Persentase (\%) } \\
\cline { 3 - 4 } & & Guru & Siswa \\
\hline 1. & I & 77,14 & 76,62 \\
2. & II & 83,85 & 82,46 \\
3. & III & 91,10 & 88,02 \\
\hline
\end{tabular}


Berdasarkan tabel 1, persentase kegiatan guru dan siswa mengalami peningkatan di setiap siklusnya. Observasi terhadap guru pada siklus I adalah $77,14 \%$, meningkat pada siklus II menjadi $83,85 \%$ dan meningkat lagi pada siklus III menjadi $91,10 \%$. Sementara persentase hasil observasi terhadap siswa juga menunjukkan peningkatan. Pada siklus I adalah 76,62\%. Pada siklus II meningkat menjadi $82,46 \%$. Pada siklus III meningkat lagi menjadi $88,02 \%$. Keduanya telah mencapai indikator kinerja yaitu $\geq 85 \%$.

Selain persentase hasil observasi terhadap guru dan siswa berikut disajikan perbandingan penilaian proses dan hasil belajar siswa pada siklus I, II, dan III.

Tabel 2. Perbandingan Persentase Ketuntasan Penilain Proses dan Hasil Keterampilan Berbicara Siswa pada Siklus I, II, dan III.

\begin{tabular}{ccc}
\hline \multirow{2}{*}{ Siklus } & \multicolumn{2}{c}{ Penilaian } \\
\cline { 2 - 3 } & Proses & Hasil \\
\hline I & $69,23 \%$ & $73,08 \%$ \\
II & $82,67 \%$ & $82,70 \%$ \\
III & $94,23 \%$ & $92,31 \%$ \\
\hline
\end{tabular}

Berdasarkan tabel 2, dapat dilihat bahwa penilaian proses dan hasil keterampilan siswa selalu mengalami peningkatan pada setiap siklusnya. Pada siklus I persentase ketuntasan proses keterampilan berbicara siswa yaitu 69,23\%, pada siklus II meningkat menjadi $82,67 \%$, pada siklus III meningkat lagi menjadi $94,23 \%$. Sedangkan pada penilain hasil keterampilan berbicara siswa, siklus I sebesar $73,08 \%$, pada siklus II meningkat menjadi $82,70 \%$, dan pada siklus III meningkat lagi menjadi $92,31 \%$.

Penerapan model pembelajaran kooperatif tipe Time Token Arends dengan media Pop Up dapat meningkatkan keaktifan, kerjasama, kemampuan berbicara/bercerita secara runtut dan jelas. Hal ini sejalan dengan pendapat Huda (2013: 241); Kurniasih \& Sani (2016: 108); Shoimin (2014: 2018) yang mengemukakan bahwa kelebihan dari penerapan model Time Token Arends yaitu, meningkatkan inisiatif dan partisipatif siswa dalam kegiatan pembelajaran, meminimalisir siswa dominan berbicara atau bahkan diam selama kegiatan pembelajaran berlangsung, meningkatkan keaktifan siswa, meningkatkan keterampilan siswa dalam berbicara, melatih siswa mengungkapkan pendapatnya melalui bahasa lisan di muka umum tanpa ada rasa malu dan takut.

Langkah-langkah penerapan model pembelajaran kooperatif tipe Time Token Arends dengan media Pop Up yang tepat yaitu: (a) penyampaian tujuan pembelajaran menggunakan media Pop Up, (b) pembagian kelompok yang beranggotakan 4-5 siswa, (c) pemberian tugas sesuai tema Pop Up, (d) pembagian kupon bicara, (e) berbicara setelah menyerahkan kupon, (f) penilain berbicara. langkah-langkah pembelajaran tersebut merupakan kesimpulan dari langkah model Time Token Arends yang dikemukakan oleh Huda (2013: 240), Shoimin (2014: 216-2017) dan Kurniasih dan Sani (2016: 108-109).

\section{SIMPULAN}

Berdasarkan pelaksanaan tindakan dan hasil pembahasan tersebut dapat disimpulkan bahwa: (1) Penerapan model pembelajaran kooperatif tipe Time Token Arends dengan media Pop Up untuk meningkatkan keterampilan berbicara pada siswa kelas III SD Negeri 3 Kalirejo tahun ajaran 2017/2018 dilaksanakan dengan langkahlangkah sebagai berikut: (a) penyampaian tujuan pembelajaran menggunakan media Pop Up, (b) pembagian kelompok yang beranggotakan 4-5 siswa, (c) pemberian tugas sesuai tema Pop Up, (d) pembagian kupon bicara, (e) berbicara setelah menyerahkan 
kupon, (f) penilaian berbicara; (2) Penerapan model pembelajaran kooperatif tipe Time Token Arends dengan media Pop Up dapat meningkatakan keterampilan berbicara pada siswa kelas III SD Negeri 3 Kalirejo tahun ajaran 2017/2018, dibuktikan dengan adanya peningkatan pembelajaran pada tiap siklusnya. Berdasarkan hasil observasi guru dalam pelaksanaan model pembelajaran kooperatif tipe Time Token Arends dengan Media Pop Up pada siklus I mencapai persentase 77,14\%,, siklus II mencapai $83,85 \%$, dan siklus III menjadi 91,10\%. Pembelajaran yang dilaksanakan siswa juga meningkat, yakni siklus I mencapai persentase $76,62 \%$, siklus II mencapai $82,46 \%$, dan siklus III mencapai $88,02 \%$. Peningkatan tersebut juga dibuktikan dengan meningkatnya keterampilan berbicara siswa yang ditinjau berdasarkan keterampilan proses aspek berbicara dan hasil belajar siswa. Peningkatan keterampilan proses aspek berbicara dibuktikan dengan persentase ketuntasan yang diperoleh pada siklus I mencapai $69,23 \%$, siklus II mencapai $82,67 \%$, dan siklus III mencapai $94,23 \%$. Selain itu, peningkatan hasil belajar siswa ditunjukkan pada siklus I persentase siswa yang tuntas mencapai 73,08\% dengan rata-rata nilai kelas 71,64, siklus II Persentase siswa yang tuntas mencapai $82,70 \%$ dengan rata- rata nilai kelas 79,62 , dan siklus III persentase siswa yang tuntas mencapai $92,31 \%$ dengan rata-rata nilai kelas 87,89 .

Berdasarkan simpulan di atas, saran yang perlu dikemukakan adalah (1) bagi siswa sebaiknya aktif memperhatikan guru dan percaya diri dalam berbicara di depan umum atau memberikan tanggapan; (2) bagi guru sebaiknya menggunakan model pembelajaran kooperatif tipe Time Token Arends dengan media Pop Up sebagai salah satu cara meningkatkan keterampilan berbicara siswa; (3) bagi sekolah hendaknya mendukung guru untuk berinovasi dalam menggunakan model dan media pembelajaran untuk meningkatkan kualitas pembelajaran pada mata pelajaran Bahasa Indonesia maupun mata pelajaran lainnya; (4) bagi peneliti lain yang hendak melaksanakan penelitian yang sejenis, sebaiknya dalam melaksanakan kegiatan pembelajaran lebih menyesuaikan dengan perkembangan ilmu pengetahuan dan teknologi.

\section{DAFTAR PUSTAKA}

Arikunto, S. (2013). Prosedur Penelitian Suatu Pendekatan Praktik. Jakarta: Rineka Cipta.

Astuti, R. (2015). Peningkatan Keterampilan Berbicara Menggunakan Media Pop Up Siswa Kelas III SD Negeri Gerobogan Kecamatan Sentolo Kabupaten Kulon ProgoTahun Ajaran 2014/2015. Skripsi. Universitas Negeri Yogyakarta.

Huda, M. (2013). Model-model Pengajaran dan Pembelajaran. Yogyakarta: Pustaka Pelajar.

Kurniasih, I \& Sani, B. (2016). Ragam Pengembangan Model Pembelajaran untuk Meningkatkan Profesionalitas Guru. Surabaya: Kata Pena.

Nurjamal, D., Sumirat, W., \& Darwis, R. (2015). Terampil Berbahasa Menyusun Karya Tulis Akademik, Memandu Acara (MC-Moderator), dan Menulis Surat. Bandung: Alfabeta.

Shoimin, A. (2014). 68 Model Pembelajaran Inovatif dalam Kurikulum 2013. Yogyakarta: Ar-Ruzz Media.

Sugiyono. (2016). Metode Penelitian Kuantitatif, Kualitatif, dan R\&D. Bandung: Alfabeta.

Tarigan, H.G. (2015). Berbicara Sebagai Suatu Keterampilan Berbahasa. Bandung: Angkasa. 